\title{
BORGES, CARRIEGO Y EL ARRABAL *
}

En 1930, Borges publica un pequeño volumen de tapas rosadas sobre Evaristo Carriego, poeta popular del Palermo de Buenos Aires de principios de siglo. 1930: año de singulares transformaciones. Borges va dejando la poesía para aproximarse lentamente a la ficción en prosa. La crisis económica y el golpe militar ponen fin al optimismo de la década anterior, que son los años mozos de la generación de Borges, y anuncian tiempos más sombríos. Obra bifronte, Evaristo Carriego resume la fase criollista, esperanzada, de su autor y anticipa la fase más experimental, desconcertante, que sigue, ya que funde en sus páginas las funciones imaginativa y crítica de un modo análogo al de ciertos cuentos que Borges da a conocer unos años después. De sus libros ensayísticos de aquellos años, es ése el primero, el más antiguo, que juzga digno de incluir, con leves retoques y algún apéndice nuevo, en la actual edición de sus obras completas. Nadie, que yo sepa, ha analizado Evaristo Carriego como un objeto literario, como etapa en una evolución creadora. Ofrezco aquí unos apuntes para un análisis de esa indole.

En los poemas escritos a lo largo de los años 20 y reunidos en Fervor de Buenos Aires, Luna de enfrente y Cuaderno San Martin, Borges casi siempre evoca los suburbios de Buenos Aires, zona de transición entre el campo y la ciudad, entre el pasado y el futuro. Procura fijar en imágenes perdurables la esencia criolla de esos barrios que van siendo lamentablemente invadidos por el progreso. En Fervor de Buenos Aires, esas imágenes son estáticas, despobladas, casi geométricas. El poeta solitario contempla, a la hora del crepúsculo, patios, calles y placitas que se abren a la inmensidad del cielo y del campo y en los que el tiempo parece detenerse un amplio instante ante la noche inminente. Los poemas subsiguientes, sobre todo los de Cuaderno San Martin, van poblándose de figuras humanas, de circunstancias, de anécdotas, de historia. Se siente cada vez más la presión del tiempo, el deseo de aferrarse a cosas queridas, el sabor del riesgo y de la muerte. Esto parece agotar las posibilidades del verso sentencioso empleado por Borges y reclamar expresión más amplia y compleja en la prosa, empezando con Evaristo Carriego, que viene a ser algo más que un simple informe crítico-biográfico.

En unas cien páginas, Borges traza un cuadro nervioso, elíptico, caleidoscópico, de Palermo a través de los siglos, apunta hechos esenciales de la vida de Carriego, analiza sus poemas y se pregunta cómo podemos captar en palabras cualquier realidad. Carriego y su $\mathrm{Pa}$ lermo, oscuros y locales, ejemplifican para Borges nuestra proble-

* Ponencia leída en el XIII Congreso Internacional de Literatura Iberoamericana, Los Ángeles, 20 de enero de 1967. 
mática situación en el universo. Ambos, poeta y barrio antiguo, ya han desaparecido, dejando sólo tenues memorias y símbolos. ¿No es ése acaso el destino de todo fenómeno, de todo momento, por intensamente que lo vivamos? Todo resulta radicalmente inestable, fugaz, contradictorio, ni una cosa ni otra. En el suburbio, "naipe de dos palos, moneda de dos caras" (18) ${ }^{1}$, lucha la dignidad contra la corrupción sobre un terreno confuso. El propio Carriego, entrerriano con sangre italiana, es minado en plena juventud por una tuberculosis mortal. Además, tanto el poeta como su barrio encerraron dentro de sus límites fatales una infinita, incalculable riqueza de detalles. Sólo podemos hacer de ellos una selección, pero ¿cómo? y ¿cómo combinarlos? Aquí Borges acuña uno de sus más intensos epigramas: "la vida es pudorosa como un delito y no sabemos cuáles son los énfasis para Dios" (20). En el capítulo sobre Palermo, Borges irónicamente "elige" un método que, querámoslo o no, nos es impuesto a todos por la flaqueza de la memoria y la comprensión humanas:

Afortunadamente, el copioso estilo de la realidad no es el único: hay el del recuerdo también, cuya esencia no es la ramificación de los hechos, sino la perduración de rasgos aislados. Esa poesía es la natural de nuestra ignorancia y no buscaré otra (16).

El capítulo siguiente, sobre la vida de Carriego, contiene un pasaje análogo, donde asoma la esperanza que Borges utópicamente quisiera fundar en esa misma flaqueza:

Yo pienso que la sucesión cronológica es inaplicable a Carriego, hombre de conversada vida y paseada. Enumerarlo, seguir el orden de sus días, me parece imposible; mejor buscar su eternidad, sus repeticiones. Sólo una descripción intemporal, morosa con amor, puede devolvérnoslo (38).

Es decir, se quiere, en la paradoja que Borges propone en otro momento, "una continuidad de figuras que cesan" (16). De ahí el carácter discontinuo y digresivo de Evaristo Carriego, que justifica el epígrafe tomado de De Quincey: "a mode of truth, not of truth coherent and central, but angular and splintered". Borges emplea las transiciones más bruscas y arbitrarias, abunda en enumeraciones heterogéneas, con evidente desprecio de las reglas convencionales de composición. $\mathrm{O}$, mejor dicho, con enorme sensibilidad a los detalles alusivos y con enorme desconfianza ante los conjuntos definitivos y armoniosos. Como declara en un apéndice, "confiamos nuestra fe a los renglones, ya que no a los capítulos" (119). Pero esos saltos abruptos y zig-zags del pensamiento crean resonancias, simetrías, que de otro modo serían imposibles. Las últimas páginas de "Una vida de Carriego" ofrecen un hermoso ejemplo. Allí Borges reitera uno de sus temas

I Las cifras entre paréntesis indican páginas de la edición de Emecé, Buenos Aires, 1955. 
centrales, anunciado antes en el poema "Inscripción en cualquier sepulcro" y llevado a su plenitud muchos años después en el magnífico ensayo "Nueva refutación del tiempo". Se trata del concepto idealista, casi místico, de que ciertas experiencias fundamentales son las mismas en todos los hombres, los identifican y asi "prueban" que el tiempo, el espacio y la muerte son irreales. Al resumir la biografía de Carriego, Borges observa:

Repensando las frecuencias de su vivir..., veo un sentido de inclusión y de círculo en su misma trivialidad. Son actos comunísimos, pero el sentido fundamental de común es el de compartido entre todos. Esas frecuencias... yo sé que nos lo acercan. Lo repiten infinitamente en nosotros, como si Carriego perdurara disperso en nuestros destinos, como si cada uno de nosotros fuera por unos segundos Carriego. Creo que literalmente así es, y que esas momentáneas identidades (ino repeticiones!) que aniquilan el supuesto correr del tiempo, prueban la eternidad (47-48).

Pero en seguida Borges pasa a preguntar si Carriego habrá vislumbrado en sus propios versos el destino que él, Borges, ve en ellos. Esto sólo lo puede conjeturar, y concluye su capítulo, a unos renglones de la cita anterior, con estas palabras:

Yo espero que Carriego lo entendió así, alegre y resignadamente, en una de sus callejeras noches finales; yo imagino que el hombre es poroso para la muerte y que su inmediación lo suele vetear de hastíos y de luz, de vigilancias milagrosas y previsiones (48-49).

Coexisten aquí las más opuestas insinuaciones. La eternidad y la disolución andan en nosotros. Carriego es Borges y nosotros y un desaparecido cuya íntima verdad ya quedó oculta para siempre. Saber, establecer identidades, es un inventar lúcido urgido por la muerte. Por supuesto, tales abismos asomaban ya en los poemas de Borges, pero aquí, en un género que se supone verídico y literal, se ahondan con disimulo, acechándonos en las rendijas más insospechadas.

No es menos ambigua la atracción que ejerce el poeta Carriego sobre Borges. Éste, entusiasta de metafísicas y literaturas lejanas, estilista oblicuo y sutil, rinde homenaje a un poeta menor, sentimental, especie de reportero en verso del arrabal, que va del ripio florido al prosaísmo deliberado. Hay en esto añoranza y admiración sinceras, pero también distanciamiento voluntario y hasta algún propósito medio socarrón de confundir los valores literarios establecidos. Siempre ha habido en Borges la nostalgia de una época más heroica en el pasado, de una plenitud que no le tocó vivir a él, así como de un lirismo inmediato, feliz, sin dudas ni artificio. Tal vez el verdadero héroe de Evaristo Carriego, retratado en varias anécdotas, sea el guapo, duelista "duro y ascético en el polvoriento suburbio" (68 n.), diestro en el arte de la sorna y de cortejar a la muerte con coraje y hombría. Carriego anduvo con confianza entre esos descendientes suburbanos del gaucho en tiempos de su apogeo, $y$ ante uno y otros Borges siente 
"esa casi perpleja admiración que el instintivo suele producir en el hombre de letras" (41). Borges hubiera querido ser un Carriego, vivir en aquella época. Pero también critica a su poeta, censurándole el patetismo fácil y el palabreo ostentoso, excesos típicos del gusto argentino aplebeyado (del tango, por ejemplo), a los que Borges por cierto no es ajeno pero que él ha sabido transformar irónicamente en artificios barrocos. A Borges le fascina el heroísmo que se confunde con la infamia; asimismo le fascina la extraña expresividad del mal gusto.

Borges publica Evaristo Carriego y no vuelve a cultivar la poesía hasta muchos años después. Es como si cediera la palabra a Carriego, antecesor suyo en la poesía del suburbio, inventor del género, privilegiado conocedor de ese mundo. Pero lo hace recreando a Carriego en un comentario densamente figurado, examen y creación suplementaria, que sobrepasa a la vez los versos de aquél y los suyos propios. Digo "sobrepasa" porque se esboza aquí una estructura multidimensional, más eficaz, que difícilmente podría realizarse en verso. Borges procura revelar la ambigüedad poética en todos los usos de la palabra -metáfora, lectura, documentación, historia, biografía, crítica, charla con el lector- que forman planos recíprocos y escalonados, como una galería de espejos o como esas filas de caserones criollos con patios y otros patios dentro, huecos, precisos e irreales, que Borges invoca vertiginosamente en su primer capítulo.

Evaristo Carriego engendra las narraciones del Borges maduro. De sus anécdotas de guapos y compadritos saldrá el primer cuento, "Hombre de la esquina rosada"; de su molde crítico-biográfico, las glosas de Historia universal de la infamia, así como, más tarde, las ficciones en forma de seudo-ensayo. Néstor Ibarra ha observado muy bien que la literatura narrativa aparece en Borges junto con la superchería de inventar obras y autores que no existen. Esto no ocurre aún en Evaristo Carriego, que contiene, no obstante, las semillas de semejante engaño creador. A decir verdad, esas semillas están ya en los primerísimos manifiestos ultraístas de Borges, donde se afirma que toda palabra o conjunto de palabras, frente al infinito y cambiante mundo, resulta tan parcial que equivale a una metáfora, vale decir una ficción. Ahondando esta teoría, se llega a dos consecuencias. Retratar a Carriego viene a ser lo mismo que imaginar a un Pierre Menard, a un Herbert Quain, a un Nils Runeberg o a cualquier otro protagonista de Borges, quienes comparten con él y con nosotros el destino del hombre mortal, ya fantasma de sí mismo, que entreteje símbolos siempre insuficientes. Y la ficción borgeana, con fábulas dentro de fábulas dentro de escrutinios críticos, devorándose en espirales que parecen no acabar nunca, viene a ser para él el símbolo menos insuficiente, más desengañado, para confesar ese nuestro paradójico destino.

Evaristo Carriego es, por lo general, un libro sereno y feliz. Al Borges de entonces todavía lo sostiene su ciudad natal. "Aquí y aquí me vino a ayudar Buenos Aires" (30), dice, parafraseando a Robert Browning; y en otro lugar supone que a Carriego también lo apo- 
yaba su barrio: "él se sabía delicado y mortal, pero leguas rosadas de Palermo estaban respaldándolo" (40). Pero Carriego muere, el barrio se deshace, y llega el momento en que a Borges no le basta con hundirse en las zonas más criollas de su Buenos Aires, aunque no pierde nunca su amor por ellas. Al emprender el género narrativo, se le abren perspectivas más vastas: su escenario pasa a ser el universo entero. El criollismo ya no funciona. Incansable refutador de sistemas, y antes que nada de los suyos propios, a Borges lo urge la necesidad de superarse. Además, los tiempos mudan, cargándose de amenazas: en 1939 reconoce con arrepentimiento que el nazismo es una forma exacerbada del nacionalismo. En el famoso cuento "La muerte y la brújula", escrito en plena guerra mundial, Buenos Aires se ve deformado como en una pesadilla, bajo nombres extraños que evocan siglos de anhelo, persecución y agonía. Lugares antes contemplados con ternura, la aventura heroica del crimen, ahora resultan sórdidos, tenebrosos, demoniacos: significan no sólo todo lo que resiste formulación intelectual, sino también lo que forja simetrías falsas para engañar al intelecto y llevarlo al fracaso, a la muerte. Es como el anverso de Evaristo Carriego, como la perfección de lo que inquietaba el fondo de sus fervorosas y entrecortadas páginas.

Princeton University.

JAMES E. IRBY 